\title{
Risk reduction by combining nature values with flood protection?
}

\author{
Jantsje M. Van Loon-Steensma ${ }^{1, a}$, and Matthijs Kok $^{2}$ \\ ${ }^{1}$ Wageningen University and Research centre, Earth System Science Group, P.0. Box 47, 6700 AA Wageningen, the Netherlands \\ ${ }^{2}$ Delft University of Technology, P.O. Box 5048, 2600 GA Delft, the Netherlands
}

\begin{abstract}
In the Netherlands, the concept of a multifunctional dike has already often been implemented, and has been identified as a promising climate adaptation measure. In a multifunctional dike, functions like urban development, transport infrastructure, recreation, agriculture or nature are deliberately combined with its primary flood protection function. This means that the design must be based on the requirements and life span of all different functions, while in a monofunctional dike only the flood protection function is considered. By accommodating other functions, a multifunctional dike may easier fit into, or even contribute to the quality of the landscape. Moreover, these other functions may help in financing the flood protection works, but governance is more complicated. To avoid costly adjustments forthcoming from changed safety standards, incorporation of multiple functions can require a more "robust" flood defence than a monofunctional flood defence. A robust flood defence can withstand more extreme situations than required by the present safety standards, and has a substantially lower flooding probability. Therefore, a multifunctional dike may be attractive in view of the uncertainties regarding the effects of climate change and a changing world. Moreover, it will result in reduced flood risk. As part of the Dutch Delta programme, several explorative studies on multifunctional dikes were initiated. Most studies focused on urban areas, but also in the rural area interest emerged for multifunctional dikes, e.g. for the integration of salt marshes into the flood defences. Marshes provide valuable habitat for vegetation and invertebrate species, and are important for wading birds. Furthermore, under condition of abundant sediment availability they can keep pace with sea level rise. Explorative modelling results indicate that vegetated forelands affect wave heights, even under extreme conditions. However, the inclusion of a vegetated foreland into the dike design does not automatically mean that nature values and flood protection are well integrated. Flood protection imposes rather different requirements on the extent and features of marshes than nature conservation and development. Wave damping is most effective with a high and stable marsh, while nature thrives with dynamic processes and differences in elevation. Therefore, only a design that allows natural marsh dynamics and includes different marsh zones could combine nature values with flood protection. In practice, this means a dike design with an uncertain foreland, that offers space for natural processes. The uncertainty in foreland development reduces the possible flood risk reduction. In our paper we describe the critical points of interest concerning risk reduction in this system.
\end{abstract}

\section{Introduction}

Since the flood disaster of 1953, the Netherlands has implemented a risk-based flood protection strategy using so-called 'dike-rings'. By law, the dike rings must protect the encircled hinterland against river floods and storm surges of a severity that could be statistically expected at a frequency varying from $1 / 1,250$ years $^{-1}$ to $1 / 10,000$ years $^{-1}$, depending on the region and the related values at risk [1]. Dike design is not only tailored to these statistically derived extreme water levels and related wave heights, but also to the allowed quantity of wave overtopping (which depends on the economic values in the hinterland and the features of the inner dike slope). Furthermore, the design anticipates to some extent on unforeseen changes and uncertainties with respect to subsidence and climate change over the planning horizon
( 50 years and 100 years for a dike in built-up areas) by adding some additional height to the calculated required height and by the reservation of a zone to allow for dike reinforcements in the future [2]. This may be called a "robust design" as the dike is designed to be slightly over-dimensioned according to the actual assessment standards at the time of construction. Dutch law prescribes not only dike design requirements, but also their periodic assessment and management. Currently the Dutch flood protection is in transition towards a new probabilistic risk approach where safety standards are expressed as flooding probabilities of parts of the dike ring area. This implies that multiple failure mechanisms for all dike sections in the dike ring must be considered, and then combined to obtain flooding probabilities for the dike ring parts. This new risk approach will be especially challenging for multifunctional dikes. In a

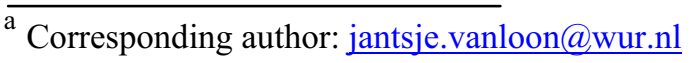


multifunctional dike, functions like urban development, transport infrastructure, recreation, agriculture or nature are deliberately combined with its primary flood protection function. This means that the design of each dike-section must be based on the requirements and life span of all different functions present, while in a monofunctional dike only the flood protection function is considered. To avoid costly adjustments forthcoming from changed standards, demographic or economic developments, or new insights, the incorporation of multiple functions often results in an over dimensioned design, i.e. a more robust design than is required from a safety perspective. Robustness can be defined as the ability of a system to remain functioning under disturbances, where the magnitude of the disturbance is variable and uncertain [e.g. 3-6].

Because a robust flood defence can withstand more extreme situations than required by the present safety standards, a multifunctional dike may be attractive in view of the uncertainties regarding the effects of climate change and a changing world. As part of the Dutch Delta programme [7], several explorative studies on multifunctional dikes were initiated. Most studies focused on urban areas, but also in the rural area interest emerged for multifunctional dikes, e.g. for the integration of salt marshes into the flood defence design [8]. Marshes provide valuable habitat for vegetation and invertebrate species [see e.g. 9, 10], and are important for wading birds [e.g. 11]. But they also function as a natural flood defence [see e.g. 12-17]. They break incoming waves, reduce wave length and velocity, and ultimately dissipate wave energy via friction with vegetation and the marsh surface [e.g. 18]. This wave damping capacity of salt marshes affects the required dike dimensions (in particular, dike slope and height) and the need for slope and toe protection structures (e.g. hard revetments and rocks). The presence of salt marshes has favourable effects on other aspects of dike design as well, such as dike stability and piping [19].

Furthermore, under conditions of abundant sediment availability they can keep pace with sea level rise [20]. Therefore, the inclusion of a vegetation foreland into the dike design forms an interesting opportunity to improve flood protection, to integrate flood protection goals with nature and landscape ambitions, and to adapt to sea-level rise.

However, a flood defence design that incorporates a vegetated foreland zone into the dike dimension does not automatically mean that nature values and flood protection are well integrated. Flood protection imposes rather different requirements on the extent and features of salt marshes than nature conservation and development [21]. Wave damping is most effective with a high, stable, and densely vegetated salt marsh, while nature thrives with dynamic processes and differences in elevation [22]. Therefore, only a design that allows - to some extent natural marsh dynamics and includes different salt-marsh zones would satisfactory combine nature values with flood protection. In practice, this means that the design of the flood defence must offer space for natural salt marsh processes and allow spatial heterogeneity and temporal dynamics in the foreshore zone. Furthermore, it implies that the design of the flood defence combines hard coastal defence infrastructure with an adjacent dynamic ecological zone, and is more characterised by a broad zone (including a rigid engineered measure) than a metered cross section of solely the hard engineered solution. This fits well in the strategy to enhance coastal resilience by e.g. the design of adaptable infrastructure, to strengthen ecosystems as part of a risk mitigation strategy, and to develop flexible adaptation plans [see e.g. 23]. In this paper we describe the critical points of interest concerning risk reduction in this system.

\section{Risk reduction by natural forelands}

\subsection{System of a hard engineered solution combined with a soft solution}

Our coastal defence system of interest consists of a dike (a hard engineered infrastructure), combined with a vegetated foreland (a soft dynamic zone) (Figure 1). The dike forms a rigid line in the coastal landscape and the physical barrier that prevent flood waters from intruding beyond a certain line in the landscape [24]. In general, a dike is built with a sand or clay core, an outer protection layer of either clay and grass or stones and asphalt, toe protection and a maintenance road. The dike is at the seaward side connected with a coastal salt marsh which forms a vegetated foreland adjacent to the dike. At this seaward side natural coastal processes (like inundation) occur. Our system can be characterized as a multifunctional dike that combines the natural, landscape or agricultural values of the foreland zone, with its primary flood protection function. Note that the dike may also represent landscape values and that both the dike and the foreland zone may represent recreational values as well.

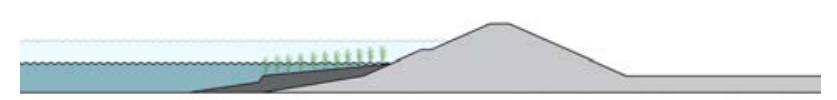

Figure 1: Coastal defence system of a hard engineered infrastructural measure (dike) with an adjacent dynamic ecological zone (a salt-marsh zone) [source: 25].

Coastal salt marshes are common in many tidaldominated temperate environments, like coastal lagoons and estuaries [22]. They occur high in the intertidal zone in sheltered conditions, rising up from the mean high water neap tide (MHWN) level landward, where the height, length and frequency of inundation by saline water decreases. The lower levels of the salt-marsh area support pioneer species. By trapping sediment, this vegetation contributes to accretion and development of creeks, rendering the environment suitable for the establishment of species that need more stable sediment. Because of the positive feedback between salt-marsh vegetation and sedimentation, vegetation forms an important aspect of salt-marsh geomorphology [22]. In addition to the tidal regime, the main physical factors that control salt-marsh dynamics (vertical and lateral accretion and erosion) are sediment supply, the wind and 
wave dynamics and rising sea level [22]. Salt marshes adapt quickly to changes in their boundary conditions. With abundant sediment supply, a salt marsh can keep pace with sea level rise by accretion or moving landwards (if there is sufficient space to accommodate them). Similarly, a change in tidal currents or wave action may change the profile of the marsh, and with it, its areal extent.

On several locations (e.g. the Wadden Sea in NorthWest Europe), measures (such as the construction of brushwood groyns, low dams of stones or clay, drainage diches) are taken to preserve or develop saltmarsh areas. Such measures aim to influence local processes of marsh formation: controlling or reducing wave action; preventing erosion and encouraging accretion to increase tidal height and allow marsh plants to develop.

\subsection{Flood risk concepts}

Flood risk can be defined as:

$$
\begin{gathered}
\text { Risk = probability (offlooding) } x \text { (societal) } \\
\text { consequences (offlooding) }
\end{gathered}
$$

In this definition the yearly probability of a defence break is multiplied with its societal consequences, such as economic damage, number of casualties, loss of protected nature area, or other metrics. This definition is widely applied by natural scientists and engineers, who usually investigate a reduction of the probability of flooding by means of improved flood defence measures or by reducing the hydraulic load.

In this framework, a new policy approach is recently implemented in the Netherlands. Now the loss of life is the backbone of flood risk policy. It has been decided that everywhere in the Netherlands the probability of loss of life has to be lower than $1 / 100,000$ per year. In the impact assessment of this safety standard, evacuation possibilities are included, taking into account the forecast window of extreme flood events and all possible evacuation routes.

Individual risk IR is location dependent, because the risk on dying depends on water depth, pace of inundation and flow speed on location $(\mathrm{x}, \mathrm{y})$. The possible flooding patterns are represented by a number of flood scenarios. The individual risk $\operatorname{IR}(\mathrm{x}, \mathrm{y})$ is calculated as:

$$
\operatorname{IR}(x, y)=\sum\left(1-E_{i}\right) P_{f, i} P_{d \mid f(x, y)}
$$

with:

$E_{i}$ : evacuation fraction of flood scenario i $P_{f, i}$ : Probability of flooding for scenario i

$P_{d \mid f(x, y)}$ : Probability of loss of life given a flood at location $(\mathrm{x}, \mathrm{y})$

Suppose that given a flood, the average mortality in a part of a city is equal to $1 / 100$ and evacuation is not possible. For a IR lower than $1 / 100,000$ per year, this results in a required safety standard of the flood defence of $1 / 1,000$ per year.

Klijn et al. [26] argue that social scientist and especially planners prefer another definition of flood risk:

$$
\begin{gathered}
\text { Risk }=(\text { flood }) \text { hazard } \cap \text { vulnerability (of the } \\
\text { society/area) }
\end{gathered}
$$

In this definition a hazard is usually regarded as a given and spatial planning and influencing people's behavior as the means to adapt to that given [26]. This definition conceptualizes the idea that a (natural) hazard only poses risk to a vulnerable society or area, and risk is based on the overlay of hazards and vulnerability. When no receptors are present in a flood prone area, then there is no risk at all. The classical flood risk approach, however, does also account for such aspects, since no loss of life and no economic damage will occur if no receptors are present. Furthermore, in loss of life models, the number of fatalities depend on water depth and the velocity of increase in the water depth.

\subsection{Effect of natural forelands on the probability of flooding}

At several locations in the temperate zone with appropriate conditions (such as a suitable tidal range, shallow water depth, sheltered from wave-attack and currents, abundant suspended sediment in the water that inundates the marsh) salt marshes can be found adjacent to the dike (Figure 2).
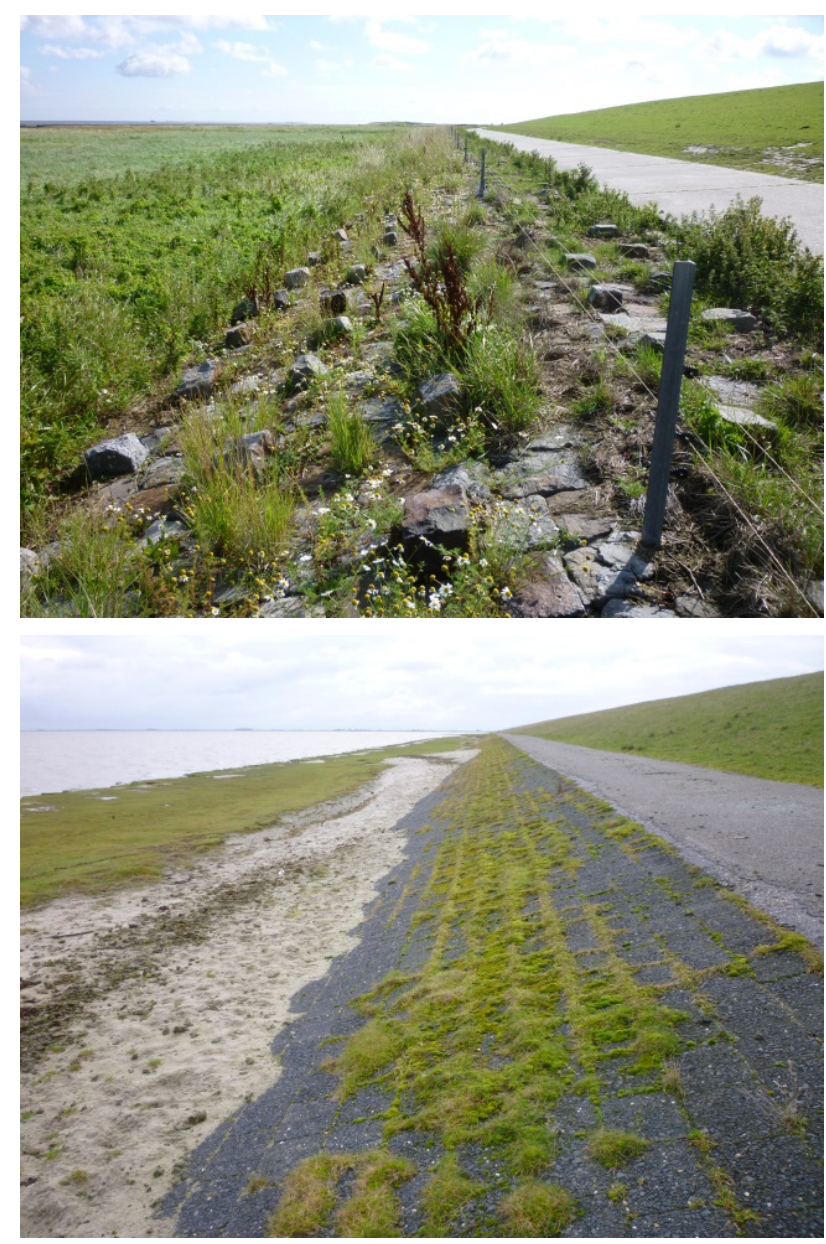

Figure 2: Dike with an adjacent broad salt-marsh zone (Elisabethgroden, Germany, top) and dike with a narrow saltmarsh zone (Dollard, Netherlands, bottom). 
This salt-marsh zone affects the near-shore hydrodynamic conditions. By dissipating wave energy, the salt-marsh zone reduces wave heights and subsequently buffers the loads on the coastline and on coastal protection works (such as dikes) [e.g. 12, 16, 17]. Some authors argue [e.g. 27] argue that forelands also may lower the storm surge levels. Furthermore, a vegetated foreland may contribute to the strength of the dike by increasing the macro-stability of the dike [19].

By taking the wave damping of the foreland into account when designing the dike, the size of the dike can be reduced. However, there are some important points of concern. The wave-damping capacity of salt marshes is affected by the width of the salt-marsh foreland, water depth above the salt marsh, topography of the coastal profile, wave height and period, as well as vegetation characteristics [see 18]. In general, waves break when they encounter shallow water depth (on the most seaward salt-marsh zone). After breaking, wave energy is further dissipated due to friction by the vegetation and the surface of the shallow zone. This often results in a reduction of wave height across the salt marsh (requiring a substantial extent of foreland). However, especially during extreme events, when flood protection is needed most, wave damping is less then under less extreme circumstances due to the high water level above the marsh surface. Although modelling [28] as well as flume experiments [29] and field observation [30] indicate that even under storm conditions salt marshes are able to substantially attenuate waves, there are still question about their performance. Furthermore, the marsh areal can be affected by lateral erosion during extreme events.

Vegetation does affect the wave-damping capacity of salt marshes not only by the plant-stem density of the vegetation present [e.g. 29, 31], but also by the height [32], stem diameters and configuration of the branches and leaves. For example, dissipation was roughly three times higher in vegetation with stiff leaves than in vegetation with flexible leaves [33]. Therefore, some saltmarsh plant species are more effective in wave damping than others. Furthermore, under natural conditions, saltmarsh vegetation is heterogeneous and grades from a seaward zone of pioneer plant species to a more mature plant community landward [9], and exhibits a seasonal pattern. Such a spatial and temporal heterogeneity also hamper the inclusion of the wave damping capacity of salt marshes in modelling.

So far in the Netherlands, the wave damping effect of a vegetated foreland has hardly explicitly been taken into account in dike design. Implicitly, however, their effect is included in the hydraulic loads, which are specified 50$100 \mathrm{~m}$ from the toe of the dike. Because wave reduction particularly occurs in the first few meters from the saltmarsh edge due to the breaking of the waves, dike heights might be somewhat over-dimensioned when a salt marsh is present within $50-100 \mathrm{~m}$. A design that does not account for the bathymetry in the near-shore zone and the wave-damping by the foreland, may offer additional protection and will likely lower the probability of flooding. On the other hand, when the presence of a saltmarsh zone is (explicitly or implicitly) included in the calculation of wave heights attacking the dike and wave overtopping, then the presence of a natural foreshore adjacent to the dike does not provide additional protection, because it is already accounted for. On the contrary, the dynamic character of the foreland zone may even pose an additional risk or maintenance task. Unless the design anticipates some spatially and temporal dynamics in the shallow foreland by not including it in the flood defence design.

\subsection{Effect of natural foreshores on exposure characteristics}

Exposure can be defined as the condition of being affected by a flood and is determined by characteristics such as flood extent, depth, pace of inundation and flow speed, and for the elements at risk and their characteristics. There are several possibilities to influence exposure determinants such as breach development, the inflow rate and volume, the flood water's pathway etc. Because a salt-marsh foreland offers some geotechnical stability to the main structure, it may affect pace of inundation after a dike-breaching. Furthermore, a vegetated foreland may prevent the continuous flooding (during subsequent normal tides) of the protected area and provide material for reparation of the dikes.

\subsection{Effects of natural foreshores on vulnerability of the flood-prone area}

We are not aware of effects of natural foreshores on the vulnerability of the hinterland. However, on many locations the hinterland concerns reclaimed salt marshes. Because of subsidence, the hinterland is sometimes more low-lying than the foreland outside the dike. This initiated thinking about the deliberated breaching of some dike sections (called managed realignment) to allow tidal influence in the depoldered area which may result in restoration of salt-marsh habitat and accretion as a result of sedimentation processes. The increase in elevation in the 'de-poldered' area will probably reduce the risk.

\begin{tabular}{|c|c|}
\hline Situation & Effect on risk \\
\hline $\begin{array}{c}\text { Wave damping capacity of } \\
\text { the present foreland } \\
\text { explicitly taken into account } \\
\text { in the flood defence design }\end{array}$ & $\begin{array}{c}\text { In case of a tailored design } \\
\text { the risk will increase due to } \\
\text { the dynamic character of the } \\
\text { salt-marsh foreland } \\
\text { In case of a deliberately } \\
\text { over dimensioned design } \\
\text { that accounts for the } \\
\text { dynamic character of the } \\
\text { salt-marsh foreland than the } \\
\text { risk will decrease }\end{array}$ \\
\hline $\begin{array}{c}\text { Wave damping capacity of } \\
\text { present foreland not taken } \\
\text { into account in the flood } \\
\text { defence design }\end{array}$ & $\begin{array}{c}\text { This will result in over } \\
\text { dimensioning of the design } \\
\text { and subsequently the risk } \\
\text { will decrease }\end{array}$ \\
\hline $\begin{array}{c}\text { Effect of present foreland on } \\
\text { exposure characteristics }\end{array}$ & No, or minor effect \\
\hline $\begin{array}{c}\text { Effect of present foreland on } \\
\text { vulnerability of hinterland }\end{array}$ & No effect on risk \\
\hline
\end{tabular}

Table 1. Effects on risk for different situations. 


\section{Risk under changing conditions}

Climate change and changes in the sediment concentration in the coastal waters are expected to change the hydraulic loads in the coastal zone. Sea-level rise, for example, will increase the frequency of extreme surge levels and the related maximum wave height. A foreland adjacent to the dike does not affect surge levels, but it can result in reduced water depths near the dike, and subsequently in reduced wave heights near the dike and less overtopping during extreme events. Another future development in coastal waters might be sediment starvation, which will induce erosion of the present saltmarsh foreland. Therefore, the question arises how a multifunctional flood defence consisting of a dike with an adjacent vegetated foreland performs during changing conditions, how it can be adapted to fulfill its protective function, and if the risk reducing capacity will be affected by adaptation to changed conditions.

Table 2 gives an overview of different situations to inform on sea-level rise, sediment regimes and adaptation possibilities.

\begin{tabular}{|c|c|}
\hline Situation & $\begin{array}{c}\text { Cross-section flood } \\
\text { defence system }\end{array}$ \\
\hline $\begin{array}{c}\text { a. Traditional dike covered } \\
\text { with a layer of clay and } \\
\text { grass and with a revetment } \\
\text { of asphalt under current } \\
\text { conditions }\end{array}$ \\
\hline $\begin{array}{c}\text { b. Dike covered with a layer } \\
\text { of clay and grass combined } \\
\text { with a vegetated foreshore } \\
\text { (multifunctional dike) }\end{array}$ \\
c. Reinforced traditional \\
dike under future conditions \\
of sea-level rise (additional \\
height and width to \\
anticipate higher surge \\
levels and higher waves and \\
additional revetment) \\
\hline d. Reinforced dike under \\
future conditions of sea- \\
level rise (additional height \\
en width to anticipate higher \\
surge levels) and abundant \\
sediment supply so that the \\
elevation of the vegetated \\
foreland can keep pace with \\
sea level rise (so that wave \\
height does not increase \\
compared to current \\
situation)
\end{tabular}

Table 2. Situations and cross sections of a multifunctional flood defence consisting of a hard engineered dike combined with a vegetated foreland.
The adaptation possibilities (c.q. measures) in Table 2 are taken to reduce the failure probability of the flood defence. Traditional measures such as improved hard revetments (of asphalt or stones) prevent erosion of the outer side of the dikes. Instead of such hard revetments, a cover of clay and grass can also prevent erosion of the defense, and they can additional result in lower waves (because of the wave damping capacity of vegetation).

The hydraulic load $(\mathrm{S})$ and the strength $(\mathrm{R})$ of the flood defence are determined by a number of uncertain (stochastic) variables. Therefore the load and the strength are stochastic variables as well. The probability that the load is larger than the strength is often defined as the flooding probability. The ultimate limit state function $\mathrm{Z}$ is defined as the difference between load and strength:

$$
Z=R-S
$$

The limit state function $Z$ defines the boundary between failure and non-failure. If the load is higher than the strength, than $\mathrm{Z}<0$, and this means failure. $\mathrm{Z}$ is a stochastic variable as well, and can be expressed by a probability density function.

A flood defence can fail in many ways (failure mechanism) and in many sections of the dike ring. Therefore, often a failure tree is built, which shows the many possible failure mechanisms and the parts of the flood defence. An example of a failure tree is given in Figure 3.

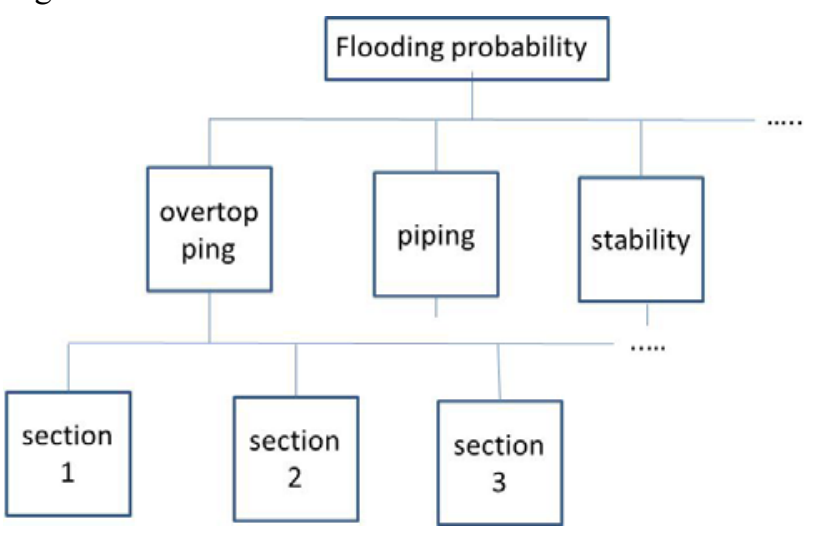

Figure 3. Example of failure tree of flood defence.

Figure 4 presents the outcome of assessing the failure probability of the dike ring of the Dutch Wadden Sea island Texel. In total, the island is surrounded by $54 \mathrm{~km}$ of flood defences. The side of the island facing the North Sea (ca. $50 \%$ ) is protected by sand dunes, while the side of the island facing the Wadden Sea is protected by dikes. The dike ring also includes several hydraulic structures. The dunes on Texel are relatively safe (because of their sand volume and regular maintenance by sand nourishment), and the probability of a breach in this dike ring section is lower than $1 / 100,000$ year $^{-1}$. The flood defences along the other side of the island (the dikes) are less safe, and the probability of a breach in this dike ring section is $1 / 270$ year $^{-1}$. 


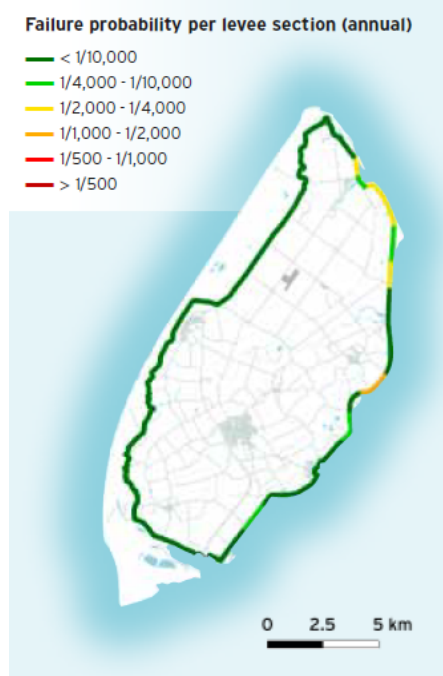

Figure 4. Annual Flooding probabilities along the island of Texel [source: 34 ].

The influence of forelands can be modelled conceptually in the probabilistic framework in a relatively straightforward way because the only process they affect is wave run up. Suppose that the relation between the exceedance frequency and the water levels and wave run up is known (for a specific location, with known properties of the flood defence, such as the slope and the roughness of the seaward face and under a given climate), see Figure 5. Then, the effect by a foreshore will be a lowering of the wave-level exceedance frequency down to (at maximum) the water-level exeeedance frequency. The exact reductions under different scenarios are not yet known and require the calibration and refining of existing models with field observations during storm events. This work is currently undertaken as part of a recently launched Dutch research programme [30].

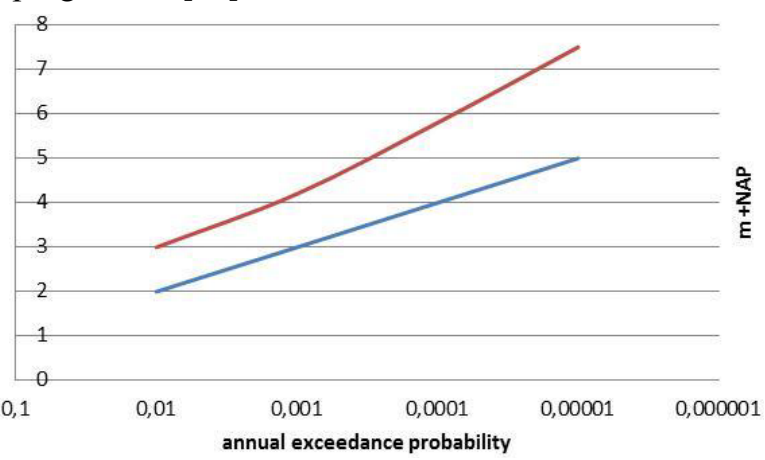

Figure 5. Relation between exceedance frequency and water levels (lower line) and wave levels (upper line).

\section{Discussion}

\subsection{Risk reduction under changing conditions}

Comparison of risk reduction by a dike with and without an adjacent foreland gives an impression of the risk reducing capacity of a multifunctional flood defence system consisting of a hard engineered dike combined with a vegetated foreland. This difference in risk reduction is entirely based on the wave damping capacity of the foreland, because the foreland will not affect extreme surge levels. The application of different situations/cross-sections for a combined flood protection system (Table 2), preferably with different realistic vegetation characteristics, forms a tool to explore the risk reduction capacity of forelands under changing conditions such as sea-level rise and sediment starvation. These cross-sections for each dike section may vary substantially along the dike ring because spatial variation in physical (bathymetry) and ecological properties (vegetation composition, density and height) of the foreland. To fully account for uncertainty in salt-marsh dynamics and spatial heterogeneity, there can be opted for a design without considering the wave damping capacity of forelands, even when they are present. The latter implies that the dimensions of the flood defence is larger, and thus probably more expensive, than strictly needed. We did not consider the situation of a vegetated foreshore without an engineered dike, since a salt marsh zone on its own would not provide the required protection of the Dutch hinterland (see Section 1).

Although there are currently ample quantitative data available on wave damping by vegetated forelands based on field studies (e.g. 30, 35-38], experiments under controlled conditions in a laboratory [e.g. 29, 39], or modelling work [e.g. 40, 28, 19], we only made a qualitative comparison because wave damping is strongly site specific and depends on the physical (extent and profile of the foreland) and the biological properties (e.g. vegetation composition, density and height) of the foreland, wave exposure (orientation, fetch), and storm surge level. On the other hand, for a given location it is possible to estimate the needed extent and profile of the foreland to guarantee the anticipated wave damping. E.g. simulations with the SWAN wave model for a study site in the Dutch Wadden Sea suggested that under storm conditions with a frequency of 5-10 times/year a vegetated foreland of some $90 \mathrm{~m}$ in width will dampen the waves more than $80 \%$, whereas under extreme conditions $\left(1 / 2000\right.$ year $\left.^{-1}\right)$ a foreland covered with dense vegetation will dampen the wave height up to $50 \%$ [28]. These modelled values were in line with field measurements of wave damping by a salt-marsh zone under a $1 / 10$ year $^{-1}$ storm event [30].

\subsection{Costs of risk reduction by a flood protection system of a hard engineered dike combined with a vegetated foreland}

Flood protection is the primary service provided by the flood protection system and is laid down in flood safety standards. So far, the flood protection standards in the Netherlands, were calculated by applying a costbenefit approach, which aims at defining the protection level that yields the lowest risk against the lowest total costs of investment and maintenance. A decision about the implementation of a measure (in our case the integration of a vegetated foreshore into the flood defence system) is therefore not only based on the risk-reducing performance, but also on the estimated costs of taking and maintaining these measures or deploying them. In 
2008 the Dutch Second Delta committee recommended to strengthen the development along with climate change and ecological processes, because these developments and measures can be cost effective and produce additional value for society [41]. So far, there are hardly any integral cost-benefit analyses of combined flood defence systems. Because of the ample experience with traditional dike reinforcement, the costs of a traditional dike reinforcement can precisely be estimated based on the calculated cross section of the dike (see cross sections in Table 2). However, despite the long tradition in saltmarsh development, and salt-marsh preservation and management in view of both land reclamation and nature conservation, the costs of salt-marsh development, preservation and management are much harder to estimate. It is possible to accurately estimate the needed volume sediment in the foreland zone to guarantee the anticipated wave damping, but this volume cannot serve as a simple indicator for the costs because of the natural processes involved. Under favorable conditions the foreland will develop naturally, which will significantly reduce the costs, while under unfavorable conditions extensive and expensive erosion protection measures, nourishment, or even site elevation are needed to develop or preserve the required foreland extent and profile.

Even, when a present foreland is not explicitly included in the flood defence design, rapid erosion and disappearance of present foreland and mud flats may require protection measures because such processes have unfavorable effects for the engineered construction. It undermines the foundation of the dikes, make their underwater slope steeper, and may induce seepage under the dike. Until the 70s of the last century the conservation of salt marshes adjacent to the Dutch Wadden Sea dikes was targeting the protection of the engineered dikes [42]. Another issue is the needed areal footprint of the foreland. A larger footprint may potentially lead to the destruction of existing, and often appreciated and protected, intertidal ecosystems [21]. Therefore, it is very difficult to generalize the cost-effectiveness of the integration of a vegetated foreland in the flood defence profile. For a reliable net cost-benefit analysis detailed site information is necessary. Furthermore, the performance in an integral assessment strongly depends on the applied functions and the weights assigned to the various evaluation criteria. Then, also information is needed about the values of the other functions of the foreland, which are sometimes hard to express in monetary values or other metrics, and may also depend on the background or view of involved stakeholders. When such other benefits are not included in the costbenefit analysis, then the combined flood protection system is valued less economically, socially and environmentally efficient and effective.

Although the combination of a vegetated foreland with an engineered solution forms a new flood protection concept, it builds on the flood protection pathway of the past. The satisfying performance and the earlier invested funds in the existing hard engineered flood defences make it economically more efficient to continue in the established pathway than reorient to fundamentally different strategies such as managed realignment [43].

\subsection{Benefits of risk reduction by a flood protection system of a dike combined with a vegetated foreland}

Estimation of avoided costs is sometimes used to gain insight in the benefits. For the South-Eastern USA coast, an area that is prone to hurricanes, based on a model using 34 major US hurricanes, the by GIS observed salt marsh loss, and the damage, that the annual value of salt marshes as flood protection ranged from USD 250 to USD 51,000 (ha yr)-1 [15].

Although salt-marsh foreland is often shaped or maintained by human interventions, this semi-natural habitat is highly valued for its ecosystem and biodiversity value (and often appointed as protected habitat) and other ecosystem services [44]. Because the integration of a vegetated foreshore in the flood defence system would probably result in an increase, or at least the preservation of salt-marsh area, this multifunctional flood defence system has potential benefits for salt-marsh related nature, agriculture, landscape, tourism and recreation. Several authors tried to estimate these benefits. The average total global economic value of the services provided by wetlands (which include the services fuel wood, raw materials, water supply, hunting, climate regulating, habitat nursery, biodiversity, water treatment, fishing, flood control, amenity/recreation and aesthetic information) was estimated to be at least USD 3,200 (ha year $^{-1}$ [45]. Other authors estimate the value of salt marshes based on values found in literature for disturbance regulation (storm protection and shoreline protection), waste treatment (nutrient removal and transformation), habitat/refugia (fish and shrimp nursery), food production (fishing, hunting, gathering, aquaculture), raw materials (fur trapping), and recreation (hunting, fishing, bird watching) USD 14,370 (ha year) ${ }^{-1}$ [46]. However, as mentioned in the former paragraph, it is very difficult to value the nature and biodiversity, landscape and cultural-heritage benefits derived from the salt-marsh foreland. When there are no differences between vegetation of a natural salt-marsh and the vegetation of the foreland, then the difference in saltmarsh area between a flood defence system with and without a vegetated foreland may form an indicator for the benefits for nature and biodiversity [47].

A challenging thought is that in a changing climate the need for the flood protection service of vegetated forelands will increase. As mentioned earlier, this flood protection service is strongly related to the extent and profile as well as the prevailing saltmarsh formation and erosion processes. In that sense a salt marsh forms a structure (stock) that provides ecosystem services (flow). The ability of salt marshes to keep pace with sea-level rise, which means that they adapt to the increasing flood protection need, makes them very beneficial for flood protection. In addition, the flood protection service of a vegetated foreshore is renewable and depletable. Healthy coastal habitats like salt marshes function as selfrepairing 'natural infrastructure' for flood mitigation, in contrast to human-built infrastructure, thus minimizing maintenance costs [48]. When they detoriate, coastal flood risk may rise. The future benefits of vegetated 
forelands will thus increase. This underpins the need for a better insight in the potential and draw-backs of integrating vegetated forelands into flood defence systems under changing conditions.

\subsection{Resilience of flood protection system of a hard engineered dike combined with a vegetated foreland}

Resilience is the ability of a system to maintain its integrity and to continue to provide services, i.e. protection against flooding. Salt-marsh ecosystems are, like most coastal sedimentary systems, extremely sensitive to changing environmental conditions [22]. Their ability to return to a former equilibrium state after an incidental disturbance and their ability to keep pace with sea-level rise and to adjust, or self-repair after a disturbance, makes them basically a resilient system. Under extreme unfavorable or steady declining conditions, when boundary conditions pass a certain tipping point, they will deteriote. Their dynamic character and the many feedback mechanisms between geomorphologic, hydrodynamic and biological processes make it difficult to predict the response and resilience of forelands and future evolution. Moreover, changes take place at a variety of temporal and spatial scales. Therefore, it is important to look at longer-term developments and take uncertainty into account. On the other hand, monitoring of short term changes may form an indicator for their resilience, because e.g. a high shortterm variability may result in erosion because vegetation are impeded to establish [49]. Additional, changes in the morphology of tidal flats may form an indicator. Tidal flats and salt marshes are may alter wave conditions and may enhance erosion or hampering marsh establishment. Although salt marshes are able to adjust to sea-level rise, climate change may affect their resilience because it combines with and amplifies several non-climate stressors on the coastal area.

\subsection{Management perspective}

Integrating vegetated forelands into the flood defence system broaden the management scope of flood protection. It adds ecosystem conservation and restoration measures to the traditional management and maintenance of the hard engineered dike. These ecosystem conservation and restoration measures are needed to modify their properties and to guarantee the presence of the foreland. Other measures involve the introduction of grazing regime to manage vegetation development, restricting human activities and other measures that can increase the ecological resilience of the foreland zone. A method to develop a foreland zone is eco-engineering, which uses the ability of so called ecosystem engineering species [50] to modify local environmental conditions and create structures that have flood protection values. For example, by trapping sediment, cordgrass plays in crucial role in the development of salt marshes. Other measures involve to stimulate foreland development are e.g. dams and groyns which manipulate environmental conditions in order to enable ecosystem engineers to settle, after which the desired structures can gradually develop [51]. Another form of soft engineering is the nourishment of sediment to the shoreline to compensate for erosion and sea level rise.

The feasibility (including the costs) of such measures is still an important and unanswered question. Other issues concern how to tune the coastal defence service of the salt-marsh foreland with other ambitions and goals [21]. How do management intervention to improve the wave-damping capacity of forelands affect nature and biodiversity, recreation, agriculture, or landscape values? How to reduce trade-offs and to realize mutual benefits? Will a strategy of management intervention on different spatial levels reduce trade-offs?

\subsection{New risk reduction approach}

In the new risk-based approach, for all dike sections all failure mechanisms must be taken into account. The spatial and temporal dynamic character of the adjacent foreshore forms a challenge. In the design of the dike ring all uncertainties of assessments and (innovative) design of a dike segment come together. This includes also the life cycle elements of a design, life extending maintenance and innovative measures. Furthermore, the multiple lines of defence work together to fulfil the safety standard.

\section{Conclusion and Recommendations}

By dissipating wave energy, a salt-marsh zone adjacent to an engineered dike reduces wave heights and subsequently buffers the loads on the dike. Therefore, a flood protection system consisting of a hard engineered dike with an adjacent dynamic vegetated foreland zone is an interesting strategy for further exploration.

Comparison of risk reduction by a dike with and without an adjacent foreland gives an impression of the risk reducing capacity of this type of multifunctional flood defence.

By taking the wave damping capacity into account when designing the dike, the size of the dike can be reduced. In case of a tailored design, however, the risk will increase due the dynamic character of the salt-marsh foreland. In case of a deliberately over-dimensioned design, that accounts for the dynamic character of the salt-marsh foreland, the risk will decrease. When the wave damping capacity of a present foreland is not taken into account in the flood defence design, then the design of the dike is more robust then needed to meet the safety standard.

Climate change and changes in the sediment concentration in the coastal waters are expected to change the hydraulic loads in the coastal zone. Therefore, it is important to explore how a multifunctional flood defence consisting of a hard engineered dike with an adjacent dynamic vegetated foreland zone performs during changing conditions, how it can be adapted to fulfil its protective functions, and if the risk reducing capacity will be affected by adaptation to changed conditions. 


\section{References}

1. Ministerie van Verkeer en Waterstaat (2007). Hydraulische Randvoorwaarden primaire waterkeringen voor de derde toetsronde 2006-2011 (HR2006). Ministerie van Verkeer en Waterstaat, Den Haag, Netherlands.

2. Rijkswaterstaat (2007). Leidraad rivieren, Ministerie van Verkeer en Waterstaat. Expertise Netwerk Waterkeren, Den Haag, Netherlands.

3. De Bruijn K.M., Klijn F., McGahey C., Mens M.J.P. and Wolfert H. (2008). Long-term strategies for flood risk management. Scenario definition and strategic alternative design. FLOODsite report T1408-01

4. Haasnoot M., Middelkoop H., Van Beek E. and Van Deursen W.P.A. (2011). A Method to Develop Sustainable Water Management Strategies for an Uncertain Future. Sustain. Dev., 19, 369-381

5. Hall J. and Solomatine D. (2008). A framework for uncertainty analysis in flood risk management decisions, Int. J. River Basin Manag., 6, 85-98

6. Mens M.J.P., Klijn F., De Bruijn K.M. and Van Beek E. (2011). The meaning of system robustness for flood risk Management, Environ. Sci. Policy, 14, 1121-1131.

7. Delta Commissioner (2010). The 2011 Delta Programme Working on the delta; Investing in a safe and attractive Netherlands, now and in the future (English version). Ministry of Transport Public Works and Water Management, Ministry of Agriculture, Nature and Food Quality, Ministry of Housing, Spatial Planning and the Environment, Den Haag. Netherlands.

8. Deltaprogramma Waddengebied (2011) Deltaprogramma 2012; probleemanalyse Waddengebied, Deltaprogramma Waddengebied, Leeuwarden, Netherlands.

9. Adam P (1990). Saltmarsh ecology. Cambridge University Press, Cambridge.

10. Bakker J.P., Bunje J., Dijkema K.S., Frikke J., Hecker N., Kers A.S., Körber P., Kohlus J. and Stock M. (2005). 7. Salt marshes. Wadden Sea Ecosystem No 19. Trilateral Monitoring and Assessment Group. Common Wadden Sea Secretariat, Wilhelmshaven, Germany, pp 163-179.

11. Laursen K., Blew J., Eskildsen K., Gunther K., Halterlein B., Kleefstra R., Luersen G., Potel P. and Schrader S. (2010). Migratory waterbirds in the Wadden Sea 1987-2008. Wadden Sea Ecosystem No.30. Common Wadden Sea Secretariat (CWSS). Joint Monitoring Group of Migratory Birds in the Wadden Sea, Wilhelmshaven, Germany.

12. Brampton A.H. (1992). Engineering significance of British saltmarshes. In: Allen JRL, Pye K (eds) Saltmarshes: morphodynamics, conservation and engineering significance. Cambridge University Press, Cambridge, pp 115-122.

13. King S.E. and Lester J.N. (1995). The value of salt marsh as a sea defence. Mar Pollut Bull., 30(3), 180-189
14. Möller I., Spencer T., French J.R., Leggett D.J. and Dixon M. (2001). The sea-defence value of salt marshes: field evidence from North Norfolk. $J$ Chart Inst Water Environ Manag 15(2), 109-116

15. Costanza R., Pérez-Maqueo O., Martinez M.L., Sutton P., Anderson S.J. and Mulder K. (2008). The value of coastal wetlands for hurricane protection. AMBIO 37(4), 241-248

16. Gedan K.B., Kirwan M.L., Wolanski E., Barbier E.B. and Silliman B.R (2011). The present and future role of coastal wetland vegetation in protecting shorelines: answering recent challenges to the paradigm. Clim Chang 106(1), 7-29

17. Shepard C.C., Crain C.M. and Beck M.W. (2011) The protective role of coastal marshes: a systematic review and meta analysis. PLoS One 6, e27374

18. Anderson M.E., Smith J.M., and McKay S.K. (2011). Wave Dissipation by Vegetation. Coastal and Hydraulics Engineering Technical Note ERDC/CHL CHETN-I-82. Vic

19. Venema J.E., Schelfhout H.A., Moerman, E. and Van Duren L.A. (2012). Kwelders en dijkveiligheid in het Waddengebied. Deltares, Delft, the Netherlands.

20. Van Goor M.A., Zitman T.J., Wang Z.B. and Stive M.J.F. (2003). Impact of sea-level rise on the morphological equilibrium state of tidal inlets. Mar Geol 202(3-4), 211-227

21. Van Loon-Steensma J.M. and Vellinga, P. (2013). Trade-offs between biodiversity and flood protection services of coastal salt marshes. Current Opinion in Environmental Sustainability 5(3-4), 320-326.

22. Allen J.R.L. (2000). Morphodynamics of Holocene salt marshes: a review sketch from the Atlantic and Southern North Sea coasts of Europe. Quat Sci Rev 19(12), 1155-1231

23. Resilient Coasts Initiative (2009). Resilient Coasts: a blueprint for action. The Heinz Center for Science. http://www.ceres.org/resources/reports/resilientcoasts-blueprint-for-action-2009

24. French, P.W. (2002). Coastal Defences: Processes, Problems and Solutions. Routledge Taylor \& Francis Group, London and New York.

25. Van Loon-Steensma J.M., Schelfhout H.A. and Vellinga P. (2014). Green adaptation by innovative dike concepts along the Dutch Wadden Sea coast. Environmental Science \& Policy 44, 108-125

26. Klijn F., Kreibich H., De Moel H. \& PenningRowsell E. (2015). Adaptive flood risk management planning based on a comprehensive flood risk conceptualisation. Mitig Adapt Strateg Glob Change. 20, 845-864

27. Wamsley T.V., Cialone M.A., Smith J.M., Ebersole B.A. and Grzegorzewski, A.S. (2009). Influence of landscape restoration and degradation on storm surge and waves in southern Louisiana. Natural Hazards 51, 207-224

28. Van Loon-Steensma J.M., Hu, Z. and Slim, P.A. in press. Modelled impact of vegetation heterogeneity and salt-marsh zonation on wave damping. Journal of Coastal Research 
29. Möller I., Kudella M., Rupprecht F., Spencer T., Paul M., Van Wesenbeeck B.K., Wolters, G., Jensen, K., Bouma, T.J., Mirands-Lange, M. and Schimmels, S. (2014). Wave attenuation over coastal salt marshes under storm conditions. Nature Geoscience, 7, 727-731

30. Vuik, N., Jonkman, S.N., Borsje, B.W. and Suzuki, T. submitted to Coastal Engineering. Nature-based flood protection: the efficiency of vegetated foreshores for reducing wave loads on coastal dikes.

31. Yang S.L., Shi B.W., Bouma T.J., Ysebaert T. and Luo, X.X. (2012). Wave attenuation at a salt marsh margin: a case study of an exposed coast on the Yangtze Estuary. Estuaries and Coasts, 35(1), 169182

32. Möller I. (2006). Quantifying saltmarsh vegetation and its effect on wave height dissipation: results from a UK East coast saltmarsh. Estuarine. Coastal and Shelf Science, 69(3-4), 337-351

33. Bouma T.J., De Vries M.B., Low, E., Peralta, G., Tánczos, I.C., Van De Koppel J. and Herman, P.M.J. (2005). Trade-offs related to ecosystem engineering: a case study on stiffness of emerging macrophytes. Ecology, 86(8), 2187-2199

34. VNK (2015). The National Flood Risk Analysis for the Netherlands. Rijkswaterstaat VNK Project Office.

35. Cooper N.J. (2005). Wave dissipation across intertidal surfaces in the Wash tidal inlet, eastern England. Journal of Coastal Research 21(1), 28-40.

36. Möller I., Spencer T., French J.R., Legett, D.J. and Dixon, M. (1999). Wave transformation over salt marshes: a field and numerical modelling study from North Norfolk, England. Estuarine, Coastal and Shelf Science 49, 411-426

37. Möller I., Spencer T. and Rawson R. (2002). Spatial and temporal variability of wave attenuation over a UK Eastcoast saltmarsh. Proceedings of the 38th International Conference on Coastal Engineering. Thomas Telford Publishing, Cardiff, London.

38. Ysebaert T., Yang, S.L, Zhang L., He Q., Bouma T.J. and Herman, P.M.J. (2011). Wave attenuation by two contrasting ecosystem engineering salt marsh macrophytes in the intertidal pioneer zone. Wetlands 31(6), 1043-1054.

39. Anderson M.E. and Smith J.M. (2014). Wave attenuation by flexible, idealized salt marsh vegetation. Coastal Engineering, 83, 82-92

40. Smale A.J. (2014). Invloed kwelderbreedte op veiligheidsopgave. Deltares memo, Deltares, Delft, the Netherlands.

41. Deltacommissie (2008). Working together with water: a living lands builds for its future; findings of the Deltacommissie 2008. Deltacommissie, Rotterdam, the Netherlands.

42. Dijkema K.S., Nicolai A., De Vlas J., Smit C.J., Jongerius H. and Nauta H. (2001). Van landaanwinning naar kwelderwerken. Rijkswaterstaat, Directie Noord-Nederland, Leeuwarden, the Netherlands.

43. Bubeck P., Kreibich H., Penning-Rowsell E.C., Botzen W.J.W., De Moel H. and Klijn F. (2013).
Explaining differences in flood management approaches in Europe and the USA: a comparative analysis. In: Klijn, F. and Schweckendiek, T. (eds). Taylor \& Francis, London, UK.

44. Barbier E.B., Hacker S.D., Kennedy C., Koch E.W., Stier A.C. and Silliman B.R. (2011). The value of estuarine and coastal ecosystem services. Ecol Monogr, 81, 169-193.

45. De Groot R. (2006). Function-analysis and valuation as a tool to assess land use conflicts in planning for sustainable, multi-functional landscapes. Landscape and Urban Planning 75, 175-186

46. Bromberg-Gedan K., Silliman B.R. and Bertness M.D. (2009). Centuries of Human-Driven Change in Salt Marsh Ecosystems. .Annu. Rev. Mar. Sci. 1, 117-41

47. Van Loon-Steensma J.M., Van Dobben H.F., Slim P.A., Huiskes H.P.J. and Dirkse G.M. (2015). Does vegetation in restored salt marshes equal naturally developed vegetation? Applied Vegetation Science 18, 674-682

48. Borsje B.W., Van Wesenbeeck B.K., Dekker F., Paalvast P., Bouma T.J., Van Katwijk M.M. and De Vries, M.B. (2011). How ecological engineering can serve in coastal protection. Ecological Engineering 37, 113-122.

49. Bouma T.J., Van Belzen J., Balke T., Zhu Z., Airoldi L., Blight A.J. et al. (2014). Identifying knowledge gaps hampering application of intertidal habitats in coastal protection : Opportunities \& steps to take. Coastal Engineering, 87, 147-157.

50. Jones C.G., Lawton J.H. and Shachak M. (1994). Organisms as Ecosystem Engineers. Oikos 69(3), 373-386.

51. Van Loon-Steensma J.M. and Slim P.A. (2013). The Impact of Erosion Protection by Stone Dams on Salt-Marsh Vegetation on Two Wadden Sea Barrier Islands. Journal of Coastal Research 29(4), 783-796 